\title{
Kei Hea Te Reo? Where is the Language?
}

Ko te patai e whaingia nei ko 'Kei hea te reo?'. E tika ana pea kia pataingia hokitia, 'He aha te reo?'

The question is 'Where is the reo?' It is also appropriate perhaps to ask 'What is the reo?'

$\mathrm{E}$ ai ki te marearea ko te reo Maaori, he momo reo mai i a Raiaatea, mai i Te Moana nui a Kiwa. Kia whakakuitihia teenei, he reo mai i Te Moana nui a Kiwa ki te Raawhiti, he reo wheenaa i teenaa ki a Rarotonga, Hawaii, Rapa Nui me ngaa moutere ki waaenganui.

The proposition usually is that te reo Maori is a Pacific language. The standard approach is to narrow that down to a language of Eastern Polynesia sharing features with the languages of the Cook Islands, Hawaii, Easter Island and points in between. 


\section{Te Tauira Tuatahi}

\section{Model One}

'He aha te reo?'

Kei roto pea eenei momo mei:

1. He aahua o te 'o' me te 'a'.

2. Ngaa momo tuumahi e rua, e toru raanei.

3. He kupu taangata peenaa i 'au', 'koe', 'koorua', 'koutou' maa.

4. He haangai peenaa i te Tuumahi-Marau- Whainga (VSO)

5. He kupu oorite i teenaa reo ki teenaa i teena moutere, teenaa.

'What is the reo?' These kinds of things are within it:,

1. Something of a case system- 'o' and ' $a$ ' in the New Zealand Maori case and variants of this throughout Polynesia and some outliers.

2. Two or possibly three verb classes- statives, universals and verbs of movement.

3. Something of a shared set of personal pronouns- 'au', 'koe', 'korua', 'koutou' etc in the

New Zealand Maori case.

4. Something of a structure of Verb-Subject-Object.

5. Something of a shared vocabulary.

Kia whakaarongia te patai, 'He aha te reo?', ki roto o eenei momo o te reo e kitea nei;

Ko teetahi tino kairangahau ko Viktor Krupa naana te kii ko te roopu reo e koorerongia nei ka tipu teenaa i teetahi waahi motuhake, atu i eetahi reo.

One important resource is Viktor Krupa (1973) who makes the point that the language group under discussion developed in relative isolation so that vocabulary and other features were not influenced to any great degree by other languages. 
Kai te koorero hoki a Krupa moo ngaa reo ki te taha, ki Melanesia, i

Sikaiana me eetahi waahi. E koorero hoki ana ia moo te reo o Haamoa me Tonga tae hoki ki nga rerekeetanga ki eetahi atu reo. Ko Krupa, kaaore ia i te tino uu moo teenei i eetahi waa. Ka koorero hoki a Krupa moo te ngaawari o te haere i teenaa reo ki teenaa i teenei rohe.

Krupa also talks of outlier forms of the Polynesian languages in Melanesia at Sikaiana and elsewhere. Then there is a distinction between Tongan and Samoan and the rest of the languages in Polynesia. This is the Central Polynesia-Eastern Polynesian distinction although Krupa seems to hedge his bets a little here. In an interesting choice of word Krupa talks of these languages as 'transparent'.

Ko te mea nui moo taa Krupa mahi ko taana koorero whaanui moo teenaa pukapuka teenaa e haangai ana ki teenei rohe. E taea e ia te whakatakotoranga whakaaro moo ngaa rereketenga, te ooritenga, te tuu motuhake raanei o eenei reo, aa, moo te wehenga ki te Raawhiti ki waaenganui raanei o te rohe.

The great value of Krupa's work is a literature review that puts work done on this language group into a useful context. This ranges from the debate on whether the Polynesian languages are dialects or separate languages (cf Capell 1933, 1961, 1961-62 1962a inter alia) to ways that the language is known and considered as with the Eastern-Central distinction mentioned above.

Kia whakakuitihia te koorero e tika ana pea kia whakaarongia taa Paaora

Moon moo te reo Maaori ki a Aotearoa (Moon 2016). He koorero moo te Haahi, te Kaawanatanga me te reo. Ko teenei hoki he hiitore kaha o te reo ki Aotearoa e toro atu ki ngaa kaupapa nui.

To narrow this down it might be appropriate to consider Paul Moon's 'Ka ngaro te reo' about te reo Maori in the AotearoaNew Zealand. It is a story of church, state and language. It is 
the first history of te reo in this country to appear in a comprehensive way.

Ko te ingoa o taa Paora Moon pukapuka ko 'Ka ngaro te reo', ka nunumi, ka waihongia ki muri pea te reo. Ka mea a Moon i te kupu 'ka', aa, ka aro ki ngaa waa e haere mai pea teenaa, ka whai raanei $i$ te aahua o te koorero. Engari kaaore i mate ai te reo, aa, ki ngaa waahi peenaa i te Urewera kiihai rawa i nunumi, aa, kai te ora tonu inaaianei.

\section{Map One: The Pacific}

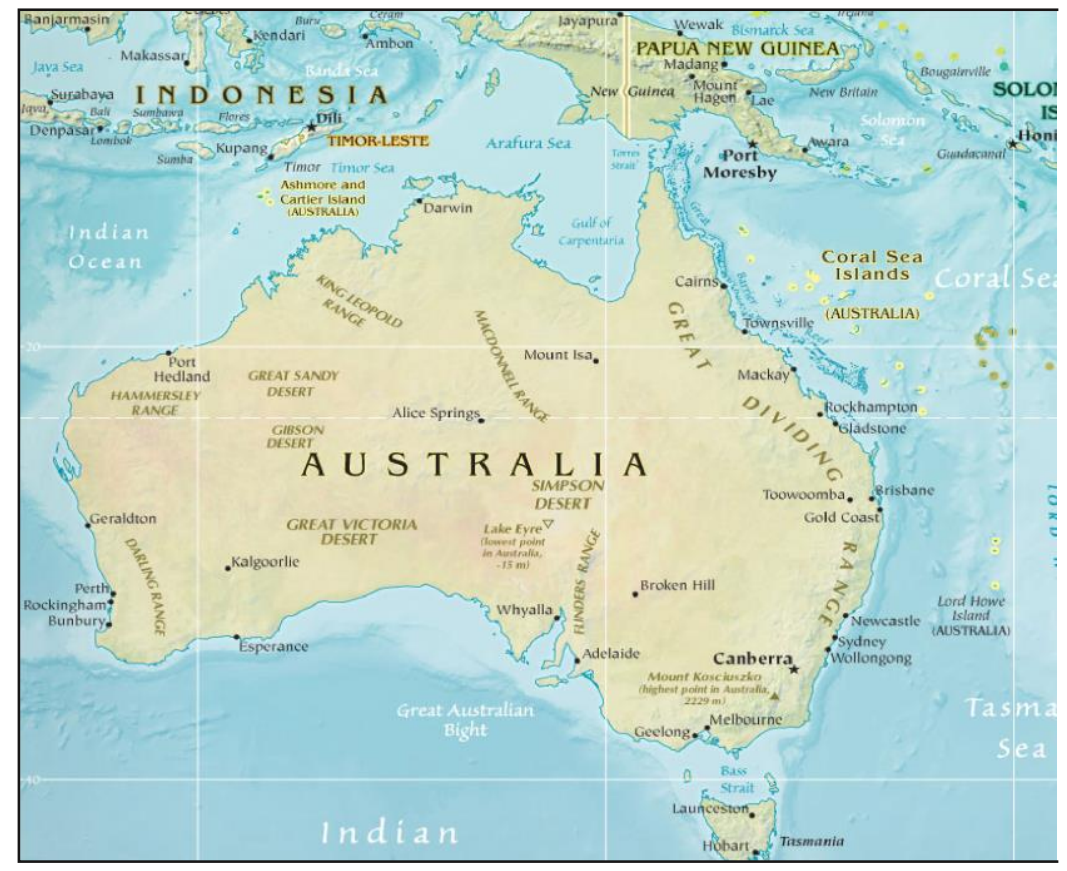


Paul Moon's book is entitled 'Ka ngaro te reo', the language disappears or is lost. There is an interesting use of the inceptive 'ka' which is a future tense marker for some and follows the tense in a conversation otherwise. But of course the language did not disappear altogether and in places like the Urewera was not disappearing in the nineteenth century and does not seem set to disappear any time soon.

E tika ana kia aata whakaarongia ngaa kupu, 'te reo'. Kai te koorerongia tonutia te reo ki te Raawhiti o te Moana nui a Kiwa engari kaaore a Moon e maatau ana ki te whiti i teenei waahi whaanui. Kua whakawhaaitihia e ia taana koorero ki Aotearoa tonu nei. Teeraa pea hai toona waa e kitea pea he koorero moo te reo o teenaa motu, teenaa, peenaa i Taahiti, i Rarotonga tae hoki ki a Aotearoa nei me, inaaianei, Ahitereiria.

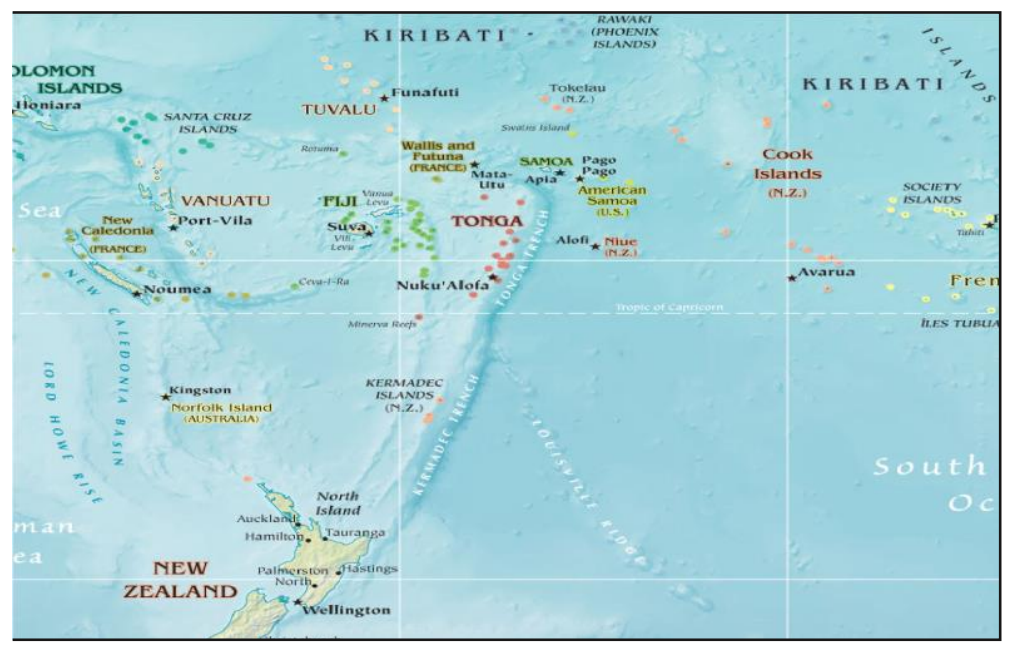


One key phrase in the title is 'te reo'. Maori is spoken across Eastern Polynesia and Moon is not attempting a history of the language across such a space and across several countries and political systems with distinct histories. He is confined to Aotearoa-New Zealand. Going forward there could well be comparative histories that consider the language in the Cook Islands, Tahiti, Hawaii as well as in this part of the Pacific. Maori is now spoken in Australia.

Ko too Moon, he hiikoitanga i teetahi haere aa waa. Atu i teenei pukapuka e rangahaungia pea te reo ki mua, ki muri raanei, ki eetahi waahi hoki ki Te Moana nui a Kiwa. Ki tua o teenaa ko te whaanui o te rangahau reo i te nuku o te ao. Ko taa Moon pukapuka he whakatuuwheratanga ki eetahi tirohanga pea.

Moon's work is one step in an important historical journey (cf Cleave 2000). From this book the subject of te reo Maori might be taken back in time to earlier days, forward to the present or laterally to other parts of Polynesia. Then there might be the breadth of comparative linguistics to consider. Moon's book is a sociolinguistic key that might be used to open various perspectives.

Kai runga i te marae e whakarongohia te kii atu o 'e nga mana, e nga reo', he tohu teenei ki teenaa ropu, teenaa e tuu ana ki te marae tae noa ki te reo-aa-iwi o teenaa roopu, teenaa. Ka noho teenei pea $\mathrm{i}$ te whakaiti o te tangata whenua ki ngaa manuhiri me te whakatuuwheratanga o te hinengaro ki teenaa mea, teenaa.

The scope of such a journey is presaged, perhaps, in the expression or its variants often used on marae of 'e nga mana, e nga reo' a form of address that salutes the specific way of talk, the voices within any group that might be on a marae and particularly those with different dialects of Maori. This recognition of voice is significant and goes with a notion of whakaiti ki ngaa manuhiri, respect and humility toward visitors, along with an attitude of openness to knowledge. 
Ko te waa paa mai, uru mai hoki o ngaa mihinare, ka whaarikitia paitia teenaa. Ka timata te pukapuka i te tau 1800 , aa, ka haere me teenaa upoko, teenaa moo eetahi tau rua tekau tae noa ki a 1899 .

The contact period and the role of the missionaries, is well documented. The book starts with a consideration of the language in 1800 and proceeds with chapters each following one or two decades until the year 1899.

Ko te tapu o te reo e meatia ana e Moon i taana upoko tuatahi, he mea nui teenaa. Kei roo tonu i te reo te matauranga pea. I te waa paa ka whakarerekeetia te reo i te uruhanga o ngaa kupu o te Paipera Tapu me eetahi mea peenaa i te kangakanga o nga heeramana, ngaa tuhinga naa teenaa, teenaa raanei.

The sacredness of the reo mentioned at the end of Moon's first chapter, the sacrosant nature in which the language contained knowledge is important and, of course it was about to change with a range of metaphors from the Bible and from church talk, from the cursings of the sailors coming to Kororareka, from the writings of the time.

Aapiti atu i eenaa mea ki runga ko te mahi tuhi, he hononga hou o te maatauranga me te reo, he aronga hou kia mau, kia tae hoki ki ngaa mahara.

Literacy itself brought with it a new combination of knowledge and language, new ways to keep and reach memories.

I te whakaotinga o te upoko tuarua e koorero ana a Moon mo te kauhau ki Oihi naa Marsden me Ruatara. I reira ngaa aahuatanga o te Haahi me te mahi tuhi e kore e roa e toro atu ki te motu whaanui.

At the end of the second chapter Moon is talking about a language situation where the sermon at Oihi in 1814 by Marsden and Ruatara has the trappings of church and literacy that were to sweep the country or large parts of it before too long.

Ka koorero a Moon moo teetahi whenua reo rua. Ki ngaa waahi peenaa i te Tai Tokerau, ki reira te reo me te Haahi me te 
tuhituhi. Ki ngaa waahi peenaa i te Urewera e kitea ana te reo koorero engari itititi ngaa kura me te tuhituhi tae hoki raa ki te whakaotinga o te rautau tekau maa iwa.

Moon talks about what might be called a two reo state where the Marsden style of church and literacy prevailed in one and the style that persisted in, say, the Urewera without the established church and with limited forms of literacy and fewer state or church based schools until at least the end of the nineteenth century existed.

Ka whai te upoko i muri nei i nga mea wheenaa i a Kendall me te wetereo. Kaaore he hua i koonei pea i teenei rautau. Ka mate kee raa te nuku ki te wetereo i muri i eetahi tiimatahanga. The next chapter considers things like Kendall and Lee's treatment of grammar. This seems to be a matter of dead ends. The study of grammar seems to have faltered and faded after some such fits and starts.

He mea iti engari he mea kaha hoki te mahi hokohoko i teenei waa. Teeraa pea e tika ana kia meatia he reo moo te ao puutea, he taputapu hokohoko te reo ki teenei mahi.

There is limited but important trade at this time and this involved te reo. We might say that in a limited way te reo is a mercantile instrument.

Ahakoa teenaa he nukuhanga nui ki te kohikohi. Kohia rawatia ngaa kupu. I ngaa mahi peenaa i te pukapuka kupu naa Wiremu. He mea nui teenei. Kia whakaarongia te reo he mea awhina ngaa kohinga kupu? E tika ana pea kia akotia te reo hai mea ora kaaore kau he kohinga noa. Ka whakaaro te kaawanatanga me te Haahi moo te reo engari hai kohinga noa kee. 
Map Two: Iwi

Rohe Iwi O Aotearoa - Map of Tribal Areas
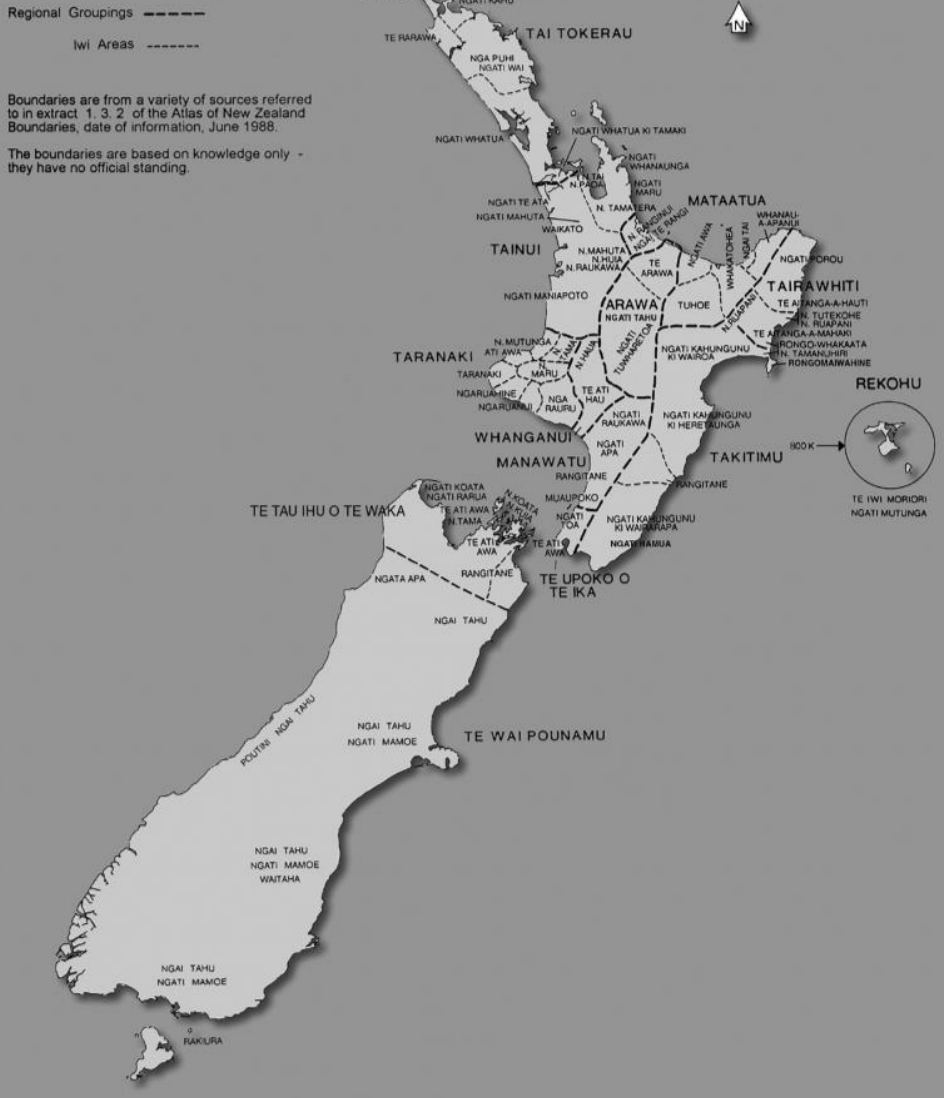
There is an emphasis though on collection, especially of vocabulary as with Williams' dictionary. Moon is stating the obvious but it is extremely important. Language is a skill set. If language is seen as a collection, something that you a learn about rather than to actually do then language loss becomes a real possibility except as a museum piece. There is no question, as Moon points out here and in subsequent chapters that attention is paid by the state and church to language, to te reo, but it is the wrong kind of attention.

E tika ana pea kia meatia mai i teenei toopito, mai raano me teenaa piki, teenaa heke raanei he taputapu haahi te reo.

It seems fair to say that te reo, from this point and with varying degrees of influence ever since has been a religious instrument.

E tika ana pea kia paataingia meenaa e arongia teetahi mahere e haangai inaaianei inahoki ko Te Reo Maori, he reo kawa teenaa moo ngaa waiata moo te motu, ngaa karakia hoki engari kaaore kau he reo koorero noa.

It might be asked to what extent a course is being set here, a course that applies today where Maori as an official language is an official ritual language to be used in anthems and prayers and stylised speech but not in everyday use.

Ko te upoko e whai nei ka haangai teenaa ki te hapori reo kootahi.

He tere kee to whakatuu o teenei kia whakaarongia te reo iti rawa. He haangaihanga o te reo Maori hai reo taawhito, he reo o ngaa kohinga, kaaore he reo moo te mahi. He peenei teenei ki eetahi aronga i teenaa waa.

The next chapter is about the monolingual nation state- its fast implementation and its totalitarian- as far as minority languages were concerned- approach. There was a making of Maori as a language of the past, of collectibles rather than usage extending earlier tendencies.

Ko te upoko e whai nei he koorero anoo moo te kohinga me te whakapatakahanga o te reo. He koorero whakakoi hinengaro moo ngaa pukapuka whakapapa. He hiitore teenei o te 
koohuruhanga o te reo i taea ai e te Kaawanatanga, he mea $\mathrm{i}$ whakarekatia e Hori Kerei me aana rangahau aa iwi me te New Zealand Society.

The next chapter has more about collecting and storing. There is an interesting discussion of whakapapa books. It is a history of language death by state sweetened by George Grey and his anthropological ventures as with the New Zealand Society.

Ko te rohe reo tuarua i meatia naa i mua, teenaa kaaore kau he Haahi tuuturu, kaaore kau he Kaawanatanga, kaaore pea he moohio ki te tuhi, he rohe peenaa i te Urewera, he waahi iti inaaianei, he rohe warewaretia e eetahi ki te Kaawanatanga haaunga anoo raa i nga hooia e whai ana i a Te Kooti, aa, ki muri o teenaa, ko Seddon.

The second reo area, the one without established church, without state, without, perhaps, literacy such as the Urewera is now a fairly small area apparently largely forgotten by many in government save the forces pursuing Te Kooti and then, at the end of the century, Seddon.

Aa, kai te tika a Moon i te nuinga o teenei. Ko te rohe tuatahi ko te nuinga o te whenua inaaianei kaaore he waahi tata noa ki a Oihi ki 1814, te waa o ngaa kauhau naa Marsden me Ruatara. Ko te paatai, e haere te reo ki hea, ki te whare kohinga taaonga, ki te urupaa raanei?

And Moon is generally correct. Reo area one is now the great majority of the country rather than a few square miles around Oihi as it was in 1814 when Marsden and Ruatara sermonised. This chapter is entitled 'forge a way forward' to which it might be added, 'forward into a museum or mausoleum'.

I muri o teenaa ka nuku te koorero ki ngaa tau 1700-1900. Ko te upoko o teenei ko 'Ngaa Aatete', aa, moo te kaha o te Kaawanatanga me te haangai o teenei kaha ki te reo, aa, moo te mate pea o te iwi Maaori me te reo Maaori. He poouri kee te aahua o te upoko nei.

And then it is on to the period 1870-1900. This has the title of 'Nga Aatete' or the resistances and is about power and the 
language thereof, about the supposed imminent death of Maori people and the Maori language. Arguably one of the most depressing periods and the chapter reads accordingly.

He nukuhanga ki roo tonu i te hapori koorero Maaaori wheenaa $\mathrm{i}$ te mahi tito waiata, te whakaaro nui moo nga hui, ngaa karawhiti peeenaa i ngaa Poukai ki te Rohe Pootae me Waikato, ki ngaa Tekau-maa-rua ki te Urewera me eetahi waahi, he waa koorero Maaori eenei. Ki ngaa Haahi Katorika, Mihinare raanei he whakauu i te reo i ngaa karakia me ngaa hiimene tae hoki raa ki eetahi wahanga o te kawa haahi. E tika ana kia meatia ai ka whakauungia te reo hai taputapu haahi $\mathrm{i}$ teenei waa.

There were moves made in the Maori speaking community to do with te reo such as the composition of waiata, the emphasis on the importance of gatherings like Poukai in the King Country and the Waikato, of Tekau ma rua, Twelfths, in Te Urewera and elsewhere that used te reo extensively. Also in the established churches Catholic as well as Anglican there was a digging in, an entrenchment with prayers and critical parts of ritual being in Maori. There is a consolidation of te reo as a religious instrument in this period.

Ko te upoko whakaoti, ka mea teenaa ko te ora o te reo he mahi tinihanga ki te wehe. Kai te tika pea teenei moo te nuinga o te motu engari kaaore moo te rohe waiho, te rohe tuarua $i$ whaingia naa e au ki runga. Ki te whakaotinga o te rau tau tekau ma iwa kaaore e mate ana te reo i te Urewera me eetahi atu waahi ki Aotearoa, ki a Rarotonga hoki. Engari ki a Hawaii peenaa te aahua ki te rohe whanui rawa o Aotearoa, te rohe $\mathrm{i}$ meatia ai hai rohe tuatahi ki runga. He mea pai pea teetahi tirohanga whaanui moo te reo ki koonei.

The last chapter suggests that the survival of te reo Maori 'was one of New Zealand's great escape acts' and this is correct for most of the country with, perhaps, the exception of the areas where Maori was not threatened. At the end of the nineteenth century there seems no threat to Cook Island Maori while there certainly is a threat to survival of Maori in Hawaii. Again, a 
comparative perspective on te reo and its history wherever spoken will be a useful addition going forward.

E koorero ana a Moon moo teetahi mahi tino kino moo teetahi reo taketake me te tatanga ki te mate i te rautau tekau maa iwa. Ka whakatakoto a Moon i eetahi ira koorero kaaore anoo kia taea ai moo, me kii, te Kaawanatanga me te Haahi, aa, ka taea hokitia pea teetahi koorero i ngaa waa e tuu mai.

In Aotearoa-New Zealand Moon is describing an appalling treatment of an indigenous language and showing how closely te reo came to language death in the nineteenth century. He offers strands of discussion, especially those to do with church and state that were not clearly set out before and allows a discussion to take place going forward.

I te tipuranga o te Kaawanatanga ka kitea te haere o te reo ki te ao paho peenaa i ngaa niupepa me ngaa pepa Kaawanatanga. Ka pai taa Moon moo teenei. Ka whaingia hokitia teenei e Mamari Stephens (Ki a Higgins maa 2014) aa, ko te pai o taa Moon ka whakakatuungia e ia teetahi kaupapa koorero moo eetahi atu rangahau moo te reo. Kaaore he kootiti roa naa Moon i teenei huarahi koorero engari he tiimata pea naana.

As the state emerges the way te reo is treated in media such as newspapers, in schools and in official documents is well covered by Moon. The latter is picked up in recent literature by Mamari Stephens (in Higgins 2014) and Moon gives a grounding to a lot of recent commentary as found in recent collections and commentaries (Higgins op cit., Cleave 2015).

Ka puta mai he reo anoo me nga huahuatau mai i ngaa Haahi, mai hoki i te Kaawanatanga. Ko nga pikitia o te Haahi me te Kaawanatanga me te paaneke o eenaa ki te reo he tohu eenaa o teetahi ao reo. Ko Moon, ka whakatakoto ia i teetahi kaupapa koorero moo teenei.

The similes and metaphors that came from church and state interaction with tangata whenua, the images of bible and government and their rendition in te reo meant a different language world, a changed reo. Moon does not venture too far 
along this path but again a platform or the beginning of one for such a discussion is provided by him.

Ko te ngaro o te reo, he mea moo eetahi taangata iti rawa e koorero ana i te reo, aa, he wao kupu hoki i ngarongia raa. He mea wheenaa teenaa $i$ te rerekeetanga o ngaa reo taketake ahakoa ki whea ki te ao.

The loss of reo was not just a matter of fewer people speaking the language but also about the loss of a coherent metaphorical system. In contact situations around the world indigenous languages were forced, and still are, into reduced or re-framed versions of the original languages.

Kia haere tonu te koorero ki tua o te rau tau tekau-maa-iwa e tika ana kia whakaarongia te Young Maaori Party me te reo. Ka puta atu teenei roopu i a Te Aute Kaareti, aa, ko teetahi puu moo te rooopu ko Thornton, te maahita nui. Ko Thornton me te YMP ka taahuri eenei taangata i eetahi kaupapa Maaori. Ko Ngata te tangata e maharatia inaaianei moo te reo engari ka tautokongia te reo e te katoa o te YMP.

To go past the nineteenth century we might consider the YMP and te reo. This group came out of Te Aute College and were inspired to some extent by Thornton the Headmaster. Thornton and the YMP changed tack on Maori issues on a number of fronts. Ngata is remembered today for his contribution to te reo but all of the YMP were concerned.

I te rau tau rua tekau ka whakatuu ngaa mea o te YMP i aa raatou anoo. Ko Poomare ka huri ia ki te Moana nui a Kiwa, ko Ngata ka huri ia ki a Aotearoa tonu. Ko te Kapa Haka, ka haere tonu teenei, aa, naa Taa Apirana te puu moo teenei. Kia whakautua ai te paatai, 'Kei hea te reo inaaianei?' ki eetahi taangata i teenei waa, kei roto i te kapa haka te reo.

The YMP started to position themselves in the early twentieth century Pomare interestingly became interested in Pacific cultures and languages.

Ngata concentrated on the local situation. Kapa Haka, encouraged by Ngata persists and is a major part of te reo today. 
To answer the question 'where is the reo?' for many people today the reo is in Kapa Haka.

E kitea pea te Kapa Haka hai tauira o te reo hai taputapu whakahaapai iwi. Ko te whakataetae ki waaenganui iwi, ka kitea teenaa hai mea whakakoi, hai mea whakakookiri hoki i te reo. He mea nui ki koonei ko te whakamau i ngaa tikanga me te reo tuuturu o teenaa iwi, teenaa. We might see kapa haka as an area where te reo is being used as an ethnic or tribal instrument. The competition between tribal groups is seen as something to sharpen and advance the language. A big feature here is the retention of customs and dialects of tribes.

I te tirohanga tuatahi ko te waa 1910-45, he waa moo eetahi mea atu i te reo. Ko te rewharewha, te pakanga tuatahi o te ao, te whakatipuranga o Ratana me eetahi mea hoki. ko te aahua o eenei mea kaaore eenaa i paa tonu ai ki te reo. Engari ko ngaa kupu wheenaa i 'Omeka' me 'Arepa' me eetahi mahi kupu wheenaa ka kitea ki reira te tango o teenaa kupu, teenaa mai i taawahi. Ko 'koata' teetahi. He rerekee teenei ki te mahi naa te Taura Whiri ki muri raa inahoki ka rapua te ao o neheraa moo ngaa kupu tika.

At first glance the period 1910-1945 is one where other preoccupations dominated. The influenza epidemic, the World Wars, the development of the Ratana Movement do not on the face of it seem to directly involve the reo. At the same time the terms Omeka, Arepa and so on are borrowings and there is a use of loan words like koata, quarters. It might be contrasted with the Maori Language Commissions emphasis later in the twentieth century on coinings from traditional sources.

Ka haere tonu te mahi kaaore hoihoi moo te whakamau i te reo ki ngaa kura noho haahi. Ahakoa ko Te Aute te tino kura e koorerongia pea he tino pai te mahi moo te reo ki a Tipene Kura, Kuini Wikitiria me eetahi kura wheenaa. Ko nga Haahi eetahi waahi pai moo te whakamau i te reo. Kia whakaarongia anootia te mahi wetereo tae hoki raa ki te iti o te mahi i teenei rohe ki te rau tau tekau maa iwa, he rawe te mahi i taea ai e Patrick Smythe ki a Tipene Kura. 
There is also the quiet work done in language maintenance by the church boarding schools. While Te Aute is often discussed at St Stephens, Queen Victoria and other Maori boarding schools kept the language alive in many respects as did the churches. Patrick Smythe at St Stephens contributed a grammar and we go back to the question as to how few grammars there were in the nineteenth century.

Ki roto o ngaa Haahi ka puta mai ngaa taangata wheenaa $i$ a Kingi Ihaka. He kaha raa oona whakaaro moo te reo, aa, i muri ka whiringia a Kingi hai Komihana Reo Maaori tuatahi. Ko toona tuakana, ko Te Raawhiti Ihaka, he mea kaha hoki ia moo te reo ki ngaa kura peenaa i a Tipene Kura.

In the churches people like Kingi Ihaka were coming though with strong attitudes to te reo, Kingi later being the first Maori language commissioner. His brother Ra kept the flame of te reo in some respects at St Stephens, an Anglican school.

Ko te Pakanga Tuarua he mea whakakoi pea i a Hoani Waititi me Hoani Rangihau moo te reo. I too raatou naa hokihanga mai ka hari raaua i oo raaua whakaaaro, Waititi ki a Tipene Kura me te Auckland Training College, Rangihau ki te Tari-toko-i-te-ora. I te Hokowhitu-a-Tuu ko Awatere teetahi tauira moo eeenei taangata. Ko Te Raawhiti Ihaka, he hooia ki te pakanga tuarua hoki ia, aa, ko taana pukapuka moo Crete ki roto $i$ te reo he tauira pai moo ngaa kura.

The second world war seems to have radicalised people like John Waititi and John Rangihau regarding te reo. When they came back they brought their thinking to their work, Waititi at St Stephens and in the Auckland training college, Rangihau in Social Welfare. They were both influenced by Awatere in the army. Te Rawhiti Ihaka hinself was a World War Two veteran and his account of Crete and elsewhere in Maaori is an important document written for school consumption.

Ko Rangihau ka whakatakoto ia i te reo ki waaenganui tonu o taana mahere, taana 'racing chart'. Ko teenei he tohu nui moo te Maoritanga me te aahua o teenaa teenaa iwi tae rawa ki, me kii Tuuhoetanga. Mai, me kii, i te tau 1960 ki teenei waa he 
taputapu te reo moo te whakahaapairanga o te iwi Maaori. I teena tau ka puta mai te Ripoata o Hunn, aaa ko taa Rangihau maa moo te reo hai taputapu whakahaapai i te iwi, he whakautu ki teenaa.

Rangihau centralised te reo in his 'racing chart'. This centrality is critical to the identity of New Zealand Maaori. We might say of this period from 1960- the year of the Hunn Report to which there is considerable reaction- to the present day that te reo is being consolidated as an ethnic and tribal instrument.

Ko Te Kotahitanga Mahuta me aana mahi moo whaikoorero me te mahi hoki naa Anne Salmond, Timoti Karetu maa moo te kawa o te marae, he whakatuunga o te reo hai mea hari tikanga teenaa. Kia whakaarongia te tau 1975, me kii, he waa teenei kia kitea ai te reo hai taaonga nui moo te iwi. Kua puta mai hoki te whakaaro o te reo hai taaonga i raro i te Tiriti o Waitangi. Ko te putahanga mai o ngaa roopu peenaa i te Wellingon Te Reo Maori Society he mea nui hoki. He whakaooritenga o te reo me te aahua o te iwi.

Mahuta (1974) coming through in the seventies harked back to the centrality of whaikorero in the King Movement. By 1975, say, the reo had begun to have a deeply symbolic sense. It had become identified as a taonga in Treaty discussions, political groups such as the Wellington Te Reo Maori Society had emerged and generally there is a greater equation of ethnic identity and language.

I teenei waa hoki ka kitea te mahi naa Katerina Mataira moo te Kohanga Reo. He hikoitanga nui teenei noo te mea ka arongia te reo me toona aahua ki ngaa tamariki.

At this time also comes the work of Katerina Mataira and the very early Kohanga Reo. This is a very important step as the language and its aspects are directed towards children.

I teenaa waa hoki ka kitea te puuawaitanga o teetahi whakaaro moo te reo Maaori hai reo aroha. Ko te upoko o taa Barry Micalfe pukapuka, 'The singing word' (1974) ko te whakaaaro ko te reo he mea o te ngaakau e tika ana kia waiatatia ai. 
There was also the idea of Maori as a romantic language, a language of love and that might best be seen in the title of Barry Mitcalfe's book, 'The singing word' (1974), the idea is that this is a language of the heart that deserves to be sung.

I te waa 1980-200 ka kitea eetahi mahi hou ki te reo irirangi me te Pouwhakaata. He waahi hou eenei moo te reo ahakoa he koorero ki runga o te reo irirangi o te motu mai i te timatahanga o te reo irirangi i teenei whenua.

The eighties and nineties saw the media developments in radio and television. These were new zones, new habitats for te reo.

$\mathrm{Ki}$ te timatahanga o teenei rau tau ka kitea te tipuranga o te reo ki runga o te ipurangi. He reo moo te ao whaanui inaianei, kaaore he reo e whakakuuitihia noatia naa ki te rohe o te iwi kaainga.

The twentyfirst century saw the development of te reo in the internet. This is a language in the wide world now, not just a language confined to the narrows of a tribal district.

Kia whakaarongia eenei mea e kitea ana te reo hai taputapu moo ngaaa haora korero ki runga $i$ te reo irirangi me te Pouwhakaata kia mau ai te putea i Te Maangai Paaho.

Regarding changes in instrumentality money talks and hourly quota of reo on radio and television in order to secure funding from Te Mangai Paho is a consideration.

Ko te whakaaro o te reo hai taonga $i$ raro $i$ te Tiriti o Waitangi, ka kitea ki reira te whakauuranga o te reo hai taputapu o te iwi, he hokinga pea ki te reo hai taputapu puutea.

The notion of re reo as a taonga in a treaty claims situation might show a further consolidation of te reo as an ethnic and tribal instrument and also a return, perhaps oblique to te reo as an economic instrument or object. One could speak of instrumentalisation and objectification.

Ko te toro atu o teenaa reo, teenaa ki te ao whaanui, ko teenei teetahi aawangawanga i eetahi waa ki eetahi taangata moo too raatou naa reo taketake. Kai roto o te pukapuka naa Paaora Moon he rahi ngaa tauira moo ngaa mea wheenaa. 
There is a sense in which people are reluctant to speak their native language in some contexts because of doubt about its reach in a global situation and Moon's book provides lots of examples of statements about a supposed or inferred inferiority of Maori and other native languages in the wider world.

Teeraa pea ki eenei momo waa ka puta mai eetahi aawangawanga moo te reo me te hinengaro. $\mathrm{E}$ ai ki te hinengaro a Waretini-Karena moo whakamaa (2014). He porohita ki koonei pea inahoki meenaa he whakamaa te kaikoorero moo te reo tonu e kore e koorero atu te tangata moo te tika me te mahi o te reo, aa, ka ngaro haere te reo. Ka puea ake hoki eetahi whakaaro moo ngaa kaituhi peenaa i a Fanon (1963).

There is, perhaps, in such circumstances doubt of language and doubt of mind. One thinks of recent literature by WaretiniKarena on whakama (2014). There is a circularity- people are whakama to speak Maori because of such doubt about the authenticity and use of their language and the whakama itself becomes a force for language loss. One also thinks of writers like Franz Fanon (1963).

Ka whakapuuhuitia pea eenei mea i te mea he reo koorero $i$ teenaa taha, he reo e tango mai i hea, i hea raanei, aa, ki teetahi taha kee he kohinga kupu nui rawa i ngaa pukapuka kupu, i ngaa whare taaonga, ki te ipurangi hoki. Engari kare kau he nui te huri ki eenei kohinga. Aapiti ki teenei ko te whakaaro ko teenei reo hirahira, he reo koorero noa moo nga mea noa.

Things compound when there is a spoken language that uses shortcuts, loan words and transliterations as all languages do on the one hand and speakers are faced with banks of collected data in dictionaries and museums that they might not use extensively on the other. In addition, there is the sense that a language redolent in imagery, a language of song, poetry and myth is rendered base as the metaphorical world of the pre contact time is threatened by contact and change.

Kaore taa Moon pukapuka e huri ana ki te whakamaa, te rangirua, te raparapa raanei moo te reo, engari kia hoki te koorero ki te whakaoorite ki te reo o Haamoa, o Tonga, o 
Rarotonga raanei me ngaa whakapae $\mathrm{i}$ te ao paho i ngaa reo o Ingarangi, o Wiiwii raanei, he mea wheenaa pea ki reira.

Moon's book does not address whakama or language doubt but coming back to the comparison with, say, Samoan or Tongan and the Central Polynesian languages or the Eastern Polynesian languages like Cook Islands Maori and Maori itself the challenges the other languages now face in regard to the onslaught of media in English or French there might be analogies to be made.

Kaaore hoki a Moon e huri ana ki ngaa taputapu hou o te rautau tekauma-iwa atu i te reo, i te taha o te reo hoki. Hai tauira ka whakarerekeetia te whakairi i ngaa taputapu hou, aa, ko te peita ki ngaa wharenui peenaa i Te Whai-o-Te-Motu ki Ruataahuna, Tokanganui-a-noho ki Te Kuiti raanei.

Also Moon does not address shifts in traditional communication in the nineteenth century other than and alongside te reo. For example whakairo changes with the new technology of chisels and instruments and the painted houses with striking symbolism found with Te Kooti's wharenui at Te Whai a te motu in Ruatahuna or at Tokanganui a noho in $\mathrm{Te}$ Kuiti.

I eetahi mahi naa teenei kaituhi (Cleave 1992) ko ngaa whata me ngaa waha o te paa, i kitea ai eenei hai mea kooreroaa-kanohi. He koorero hoki naaku moo ngaa whata kai ki te Taitokerau.

In earlier work by the present writer (Cleave XXXX, cf Best XXXX) the way platforms and entrances to pa Maori along with the kai platforms described at contact in the north considered visual communication.

I te wa paa ka kitea he torohanga o te reo ki eetahi mea hou. Ka whakahoungia ngaa waiata peenaa i a Pinepine te kura i te nuku o te rau tau tekau-ma-iwa kia whaia ai te mamae me ngaa maahere o Ngai Maaori. Ka kitea ki reira ngaa moemoea, ngaa poropitihanga i te nuku o te ao koorero ki te Urewera ki te Rohe Pootae o te Kiingitanga hoki. 
At contact there is a stretching and realignment of communication going on and te reo is a part of that. Traditional waiata like Pinepine te kura are revamped and to a certain extent rephrased as the nineteenth century goes by to express the pain and prospects of Maori. While there might be doubt there is also experiment and prophecy across a broad swathe of communication especially in what has been called language area two in this review, in the King Country and the Urewera.

He rahi pea ngaa tatanga hiitore. Ko te hiitore o ngaa puunaha mahara, e whakaarongia eenaa i te taha o te hiitore o te reo. Kai roo hinengaro, kei waho hinengaro hoki ngaa huarahi kia whaia ai ngaa kupu, raarangi kupu me ngaa kaupapa. Ko te mahi kohi e koorerongia naa e Moon he nuku ki waho o te hinengaro tangata, he nukuranga i aro ai ki nga rorohiko me ngaa karetao koorero pea.

There are various historical approaches. The history of memory systems can be set alongside the history of language. There is in mind and outside mind, internal and external ways of recall for words, phrases and content. The collection emphasis set out by Moon is a move into the externalisation of language, the beginning of a process that could end with interactive language avatars.

He rerekeehanga hoki i te mahi whakapapa,whakaraarangi hoki mai i te waa paa. Ka uru mai nga puunaha peenaa i te mea Linnaean, te haere o ngaa reta Roomana me eetahi mea, aa, i te rautau rua tekau ka kitea te maahere matihiko. Ko te tere hoki o te mahi ki roto, ki waho raanei o te hinengaro tangata. Ko teetahi mea ko ngaa raarangi, ngaa kohinga raarangi hoki.

There are changes in classification over the period from the time of contact and traditional systems of whakapapa and other traditional ways of classifying things and people. We have the nineteenth century standards, alphabetical, Linnaean and other and then the shift to digital in the twentieth century. There is speed of recall in and outside the personal brain. There is file then there is the arrangement of files, the sets, the banks the crisses and the crosses. 
Ko teetahi whakaaro moo te mahi tuhi, e kitea ana te reo $\mathrm{i}$ waho o te waha, i waho o te tangata. Ko teenei, he kohinga tuatahi, he rarangi tuatahi, he nukuhanga hinengaro moo te reo. Ka tiimata eenei mea e koorerongia naa peenaa i te mahara ki te roro hiko, te karetao e koorero ana i te reo maa teetahi rorohiko i te mahi tuhi.

It might be possible to look at the literature on literacy and think about

it in terms of externalisation. With literacy people see their language outside themselves. This is a first collection, a first file, a reification to shift consciousness of communication. The steps outlined above; the collections of vocabulary, the filing, the digital processing and on to robotics, language avatars and on to fantasies of the future, all began, in a certain way with literacy.

He rahi hoki nga tirohanga ki mua ki te rau tau tekau-maiwa. Ko teetahi mea ko te hiitore o te Moana nui a Kiwa whaanui, te hitore o Aotearoa hoki. Ko teetahi anoo mea ko te hiitore o te Kaawanatanga me te reo. E taea hokitia te koorero moo ngaa Tekau-maa -rua me ngaa Poukai.

Nineteenth century history can be told in various ways. There is Pacific history and New Zealand history. There is the nation-state perspective and the problem here with a history of language is that NZ Maori is a dialect. Then there is the local perspective looking at, say, Twelfths or Poukai.

He mea hoki ngaa hiitore o te kupu me te aahua. Ngaa kupu $\mathrm{i}$ te taha o te whakairo me ngaa rerekeehanga $\mathrm{i}$ te iro me te tae. Aa, ko ngaa kupu $i$ te taha o ngaa whakaahua, me te nukuhanga ki te ao whakaaua ki te rau tau tekau-maa-iwa. Ka whai mai ngaa pikitia, te pouwhakaata, te ipurangi tae noa ki ngaa pikitia ki te haa...

Then there are the histories of word and image. Words to go with carving and the changes in carving and colour. Then words to go with photos from the mid nineteenth century the transition from a world without photographic image in 1800 to 
one with the image later in the century. Then movies, then television, the net and on to holograms...

I eetahi tauira o ngaa reta ki te rau tau tekau -ma-iwi kaaore e rangahaungia ana e Moon peenaa i eenaa naa Wiremu Tamihana he rahi nga huahuatau taawhito. E tika ana pea kia whakaarotia te nuku i te ao huahuatau rawa ki te paku kore o teenaa momo aahua.

In some examples of nineteenth century letters not discussed by Moon such as those written by Wiremu Tamihana there is an extensive use of traditional metaphors. There may be a profit in looking at a range of metaphorical use ranging from the rich to the low use of metaphor.

E tika ana pea kia huri ai te koorero ki te karere-aa-waea peenaa $i$ te terekaraawhe ki ngaa rau tau tekau-maa-iwa, rua tekau ranei. He iti pea nga huahuatau i teenei mahi. Kia whakaarongia ngaa ripoata paremata, he peenaa eenaa hoki.

Text messaging in te reo in the twenty first century is, perhaps similar to the use of telegraph or military despatch in the nineteenth and twentieth centuries and not discussed by Moon. This would seem mainly to do with communication of direct information rather than the metaphorically informed so to speak (Meyerhoff 2016 and writers referred to in He Tono).

Teeraa pea ka paa nga upoko whakoti naa Moon me ngaa huringa ki ngaa ripoata paremata tae hoki ki te iti o te whakaaro moo eenaa ki te hapori whanui ki aa Stephens (in Higgins et al. ed 2014). Ko te puutake pea, he iti te haangai ki ngaa hapori, hre amroke hoki te reo ki roto o eenaa tuhinga. He rarangi rangahau moo ngaa raa e tuu mai pea.

Moon's concluding chapters with their reference to parliamentary reports and the lack of response to them described by Stephens in the twentieth century might be to do with a low level of information perceived as directly relevant to Maori speaking communities at that time and a low level of interesting or attractive metaphor. This is a line, perhaps, for future research. 
E tika ana kia ara whakaarongia ngaa aahua o te ako i te reo me ngaa huahuatau. Ko Bereiter raaua ko Scardamalia eetahi taangata tuhi ki teenei rohe. Teera pea kai te ngaro haere eetahi aahua koorero $i$ te whakawhaitihanga, te whakarerekeehanga ranei o ngaa huahuatau mai $i$ te ao taawhito. Teeraa pea ka puta mai te whakamaa i teenei ngarohanga.

There is another sense in which metaphor is important and that is in language learning. Bereiter and Scardamalia talk about forms of literacy involving basic and then complex communication involving metaphor. What happens when the metaphorical systems of a language are rendered askew in a cultural contact situation. Could it be that, to take Moon's title, 'Ka ngaro te reo' could it have been and is it still the case that te reo is being lost in the ways in which it is taught with specific reference to metaphorical use? Looking back over the points above there may be a need to look, both in Moon's work and elsewhere, to the use of metaphor or its avoidance in terms of whakama, of shame and avoidance, of doubt of language and mind all in terms of language loss.

Ko teetahi mea ko te whakaaro moo te reo hai reo rangatira. He whakaaro teenei kai tua i te koorerorero o te reo, aa, he mahi haangai raanei ki teetahi reanga teitei. E whakarongohia teenei $\mathrm{i}$ te marae $\mathrm{i}$ te koorero moo te nuku ki te Maaori i te reo Pakehaa.

There is also a notion of te reo which finds its expression in the title of Timoti Karetu's book, 'Te Reo Rangatira' (1974). There is a sense in which te reo is more than just a means of communication, that there is a language of chiefs, of a higher order of metaphor and symbolism than, perhaps, other languages. The expression is heard on marae when people turn to and from Maori and English.

Aa, i nga waa o mua ki runga i te marae e kitea ana eetahi momo koorero. Hai tauira ki runga i te marae tonu ka tootika kee te koorero, aa, ka tuu te puehu engari ki roo wharenui he marie kee te koorero pea. Naa reira kia moohiotia te mahi tika i 
te reo, he mea nui teenaa, he mea mana, aa, ka hoki taatou pea ki 'e nga mana, e nga reo'.

And traditionally in the marae situation there are kinds of expression involved. For example on the marae itself the language can be direct and aggressive, the dust can be raised while in the wharenui a more peaceful approach is to be taken. So knowing how to use the language as well as to actually speak it is important. It is a matter of respect, dignity and presence and we come back, perhaps, to the expression, 'E nga mana, e nga reo.

Teeraa pea ko ngaa whakaaro moo te reo, he mea kaha moo te koorero me te whakamau i te reo. Ko te koorero i te ruma ako, $i$ te reo irirangi, $i$ te pouwhakaata, ki runga o te huarahi hoki, he mea ngaawari, aa, he mea tika hoki. He mea nui kia kore e kitea teetahi tuuwatawata-aa-reo e aukati ana i te tangata ki te nuku atu i te reo kawa. He mea tapu, he mea noa hoki te reo.

It may be that conceptions of a language are a significant factor it its use and retention. Using te reo in classrooms, on radio and on television and, above all, on the street involves informal as well as formal modes of expression. Language inhibitions, fences, if you like, may not help.

He mea nui kia kore e puta mai te reo hai tuuwatawata kia kore e uru mai eetahi kaikoorero hou. E whakauauatia pea te koorero noa i teenaa.

It is important that the formal, the culturally approved, might not move from being a firewall considered necessary in a politicised environment where a community has been under threat to a walled language area, a language prison, a cultural cage to take a phrase from Cheryl Te Waerea Smith (!996?) in effect that is difficult to get of in order to communicate effectively on the street in everyday situations, in noa as well as tapu contexts. 


\section{He koorero whakaoti Concluding Comments}

Ka tiimata te koorero ki runga i te whakaaro moo ngaa roopu ki te taha ki Melanesia. E tika ana pea kia huri ano ai te koorero ki teenaa. Ko te reo Maaori o Aotearoa, he reo ki te taha inaaianei? Ka whai teenei whakaaro i te mahi kohikohi i taea ai mai i te waa o Hori Kerei. Ka haere tonu teenaa i teenaa waa ki naaianei i te Taura Whiri i te Reo me te mahi kohi kupu hou ki reira i eetahi atu waahi hoki. Ko te putahanga mai o te reo irirangi me te pouwhakaata Maaori, kua aapiti eenaa mea ki te whakamotuhakehanga o te reo Maaori ki Aotearoa. Ko te reo Maori o Aotearoa, naa ngaa mea ki runga e tuu ana hai reo motuhake i eetahi, engari raa, naa eenei mea e tuu ana teenei reo hai maaramatanga moo eetahi momo o te reo i eetahi waahi.

The discussion above started with the concept of outlier groups these being in Melanesia. It may be time now as we look forward to revisit this idea. It may be that New Zealand Maori itself is now an outlier. This follows the collection policies of George Grey and others at contact and thoughout the nineteenth century as discussed above and extends into the way the language has developed in this country with, for example, Maori radio and television and the way Te Taura Whiri o Te Reo has coined vocabulary. New Zealand Maori might be an outlier having developed in this way but at the same time it might be seen as a leading light with other variants of the reo to the side.

E tika ana pea kia rangahaungia anootia te whakaaro o te mea ki te taha e whaingia naa e Krupa inahoki kua haria mai te reo i te tonga o Haina. Ko te whakaaro pea ka peke te reo $\mathrm{i}$ teenaa moutere ki teenaa i te nukuhanga. Naa teenaa pea ko te aahua tuatahi o te reo, ka kitea teenaa ki a Melanesia. Naa teenaa anoo pea ko te ingoa tika moo te reo ko Sikaian.

The concept itself of an outlier as employed by Krupa could be revised on the grounds that the language was carried from South China. On that basis and assuming that the islands were settled on an 'island hopping' basis, one to the next, the form of the Polynesian languages found in Melanesia is earlier and 
primary to those found in Polynesia. One might ask whether the name of the language might best be taken from its first point of formation, its first recognisable form and so the language might be called Sikaian...

Mai i teenaa tirohanga ko te waahi e kiia nei ko Polynesia ko teenaa pea te waahi ki te taha. E tika ana pea kia aata rangahaungia te reo koorero i ngaa motu peenaa i a Sikaiana i runga o te whakaaro ko teenei te putahanga tuatahi o te reo.

This could, in this sense, make the Polynesian space the outlier area. There could even be a case for a much more detailed study of the so called outlier areas like Sikaiana in Melanesia as first formations of the language.

Meenaa ka tangohia atu te kupu 'Polynesia' i te koorero ka waiho te koorero moo te reo o eetahi aahua motuhake $\mathrm{i}$ koorerongia ai ki mua. Ka koorero a Krupa moo te ngaawari o te moohio $i$ te reo e koorerongia naa $i$ te nuku o te moana atu $i$ a Sikaiana ki a Rapa Nui, i Hawai'i ki Aotearoa i runga i te aro o te kupu 'transparent'. Kia hoki ai te koorero ki te whakaraarangihanga o eetahi aahua $o$ teenei reo $i$ te timatahanga o teenei tuhinga.

If we take the word 'Polynesia' out of the discussion for a moment this leaves us with an analysis of a language that, as stated above, shares certain characteristics as set out at the beginning of this Monograph. Krupa talks of the languages from Sikaiana to Easter Island as being 'transparent' possibly for these shared characteristics among other reasons. We could go back to the listing of features in this language at the beginning of this essay.

Kia huri whakamua ai taatou e tika ana pea kia whakaarongia anootia te waahi me toona haangai ki te reo koorero. I te wao o te reo irirangi, te pouwhakaata me te ipurangi kaaore pea e haangai te aahua o te reo ki teenaa waahi, teenaa ranei. E whakarongohia ana te kaiwhakapaaho ki a Papaioia i ngaa waahi peenaa i a Raanana, i a Los Angeles, i te nuku o te ao hoki. 
As we look ahead it may be that the physical locality involved and its relation to spoken form ought to be revised. In the age of radio, television and the internet dialect need not be bound to district. A DJ on a Maori station operating out of a provincial area like Palmerston North is heard on the net in London and Los Angeles as well as throughout the world.

E noho ana taatou i teetahi waa moo eetahi kaikoorero hou i te reo i meatia ai ki mua i teenaa rohe, teenaa. Hai tauira kia whakaritea ai ngaa mea koorero ki Aotearoa me Ahitereiria ki ngaa mea koorero ki Aotearoa me te Moana nui a Kiwa teeraa pea ka ohoreretia te tangata. He peenaa hoki pea kia whakaarongia ngaa taangata kaaore he whakapapa Maaori e koorero ana i te reo.

We live in an age of new speakers where the language broadly described above is spoken in various areas. For example if one compared the speakers of this language in New Zealand and Australia to those in New Zealand and Polynesia one might be surprised. If one looked at speakers with no Polynesian heritage one also might be surprised.

Ko te kupu 'maaori', mai i te whakaaro teenei o te whenua tonu, o te wai uu tika kia whakaarongia pea te wai maaori me te wai tai. Naa teenaa kupu ngaa taangata Maaori me te reo Maaori. I mua i te waa paa kaaore he kupu moo te reo tonu haaunga pea $\mathrm{i}$ te reo koorero o ngaa tuupuna, o teenaa iwi teenaa raanei kia whakaarongia ngaa rerekeehanga iti o teenaa rohe teenaa.

The word 'maori' comes from the idea of being of the land, of being natural as with wai Maori or fresh water and compared to wai tai or salt water. So we have tangata Maori, Maori people and te reo Maori, the Maori language. Prior to contact there was no word for the language itself except perhaps as te reo o nga tupuna the language of the ancestors or, perhaps of this or that tribal group with reference to slight dialectal difference.

E haangai tika te kupu 'maaori' ki te reo o naaiainei i oona aahua katoa? He pai kia kiia ai ngaa kupu peenaa i a 'Polynesian', Maaori raanei i te wao koorero o te ao katoa maa 
runga $i$ te ipurangi. Ka mea a Krupa ka tipu te reo atu i te ao whaanui engari inaaianei kua taiaawhiotia te ao ki te ipurangi, aa, kua nuku te waahi koorero.

Does the word 'maori' accurately describe the language now in all its aspects? Is it accurate to use such words as 'Polynesian' or 'Maori' in the context of the language spoken now outside Polynesia and globally on the internet? Krupa pointed out that the language in this part of the pacific developed in relative isolation. That isolation no longer exists and the locus of speech has shifted.

Ka whai mai pea te whakaaro, te paatai raanei moo te maharatanga. Ka hoki au ki a Hori Kerei me te mahi kohokohi ki te rau tau tekau-ma-iwa. Naa te rahi o ngaa mea i kohia me te taahuritahga ki te rorohiko me te putahanga mai hoki o te hinengaro rorohiko (AI) kua puta mai teetahi ao koorero hou kia whakaarohia ngaa karetao e koorero ana me eenaa momo mea.

Then there is the question of what I will call the 'memory effect', the effect of George Grey and others as they collected and stored aspects of the language in the nineteenth century- again this is one reason why Moon's book with its attention to the collection process in the nineteenth century is important- the subsequent digitisation of those collections aided by the coinings of te Taura Whiri, also digitised, to now give an information base to talking dolls and the like using AI.

Ko te hua whakaoti ki teenei waa o te maharatanga reo ko te karetao whaanui e koorero ki a ia anoo, he roopu karetao raanei e koorero ana ki ngaa taangata i eetahi waa e hari raanei ai i teetahi koorero i roo tonu i te roopu. Kai te haere teenei ki waho o teetahi iwi taketake?

The ultimate product, so far at least, of the memory effect is a kind of externalised language avatar talking to itself or a series of avatars sometimes talking with people where te reo exists, a language avatar universe, as it were, that continues and develops without, it might be asked, a specific ethnie.

Ko teehai tirohanga, e korero ana taatou mo he ipurangi kaaore he whakaaro moo whakapapa. Kua tae taatou ki teetahi 
ripeka. I mua ko te hiitore o te whakakahoretanga o te reo I meatia ai ai e Moon, e whakahokitia e eetahi, he taraiwa teenaa ki te waa e whai nei. Ka puta mai taa Orwell ki te hinengaro; 'who controls the past controls the future'. Engari kaaore au i te moohio ka pai a Orwell ki te wao o te ipurangi hai mea tira...

Another way to put this might be to say that the archive of te reo on the net has no historical consciousness. We may have reached a critical point. Heretofore the history of language shutdown so well described by Moon and espoused by others has been a driver into the future and of course one thinks of Orwell saying in his novel 1984 'who controls the past controls the future'. I'm not sure whether Orwell would be happy with the AI machine looking after things....

He koorero naa ngaa karetao engari he aronga ki te koorero? Ahakoa pea te iti o te nako kai te ora tonu te reo. Ko te mea, he wheena ngaa karetao i ngaa tamariki i a raatou e koorero ana e tuu tonu te reo. Ka tuuwhera mai teetahi anoo kuaha ki koonei. I te wao koorero o ngaa karetao me eetahi kaihari mihini o te reo ka nuku te reo ki eetahi waahi hou atu pea i teetahi kawa ki teetahi rohe ki teetahi wao whaanui e toro atu ana ki eetahi pae hou.

Dolls, robots and other AI language carriers may talk but do they argue coherently and make sense? But then who said a language needed to be philosophical to survive? The fact that language avatars talk in baby talk or whatever now may be irrelevant to the question of language survival. That opens another box of tricks. As AI develops in the language area the echo talk of the doll segues and lurches into different sentences and patterns and possibilities of interaction. Away from specific cultural matters into something of a nebulous language stratosphere.

Ko teetahi whakaaro ko te reo maharatia, he reo anoo ki te taha teenei pea.

Another way to think about it might be to say that the language in the digital memory now is another outlier. 
He tika te koorero e nunumi ana te reo i te waa tonu o te maharatanga? Aa, ki teenaa taha e meatia mai te whakaaro kai te nunumi ana te reo, aa, ki teeraa taha ka kitea te maharatanga o te reo me te matihikohanga o te reo hoki.

We have the idea of a language being endangered even as it is remembered. To take the title of Paul Moon's book, Ka ngaro te reo, the language disappears, the collection process espoused by Grey and others and put together with developments in new technology and digitisation from later in the twentieth century may mean that the concept of endangerment be thought through again.

Kia whakaarongia te reo Maaori hai momo reo, kaaore he reo tuu motuhake ana e tika ana pea kia whakaarongia anootia hoki te whakaaro e nunumi ana te reo. Kia mate, me kii, te reo Maaori o Wharekauri engari ka ora te reo Maaori o Pukapuka he nunumihanga o te reo noa atu, he nunumihanga o teetahi aahua reo raanei?

When New Zealand Maori is considered as a variant of the language rather than as a stand alone language the concept of endangerment and the idea that the language is disappearing may need to be considered again on that basis as well. If the variant in Stewart Island ceases to exist and the variant in Pukapuka continues can we really speak of language endangerment as opposed to say, dialectal disappearance?

Ko teetahi mea ko te aro o te koorero. Ka haangai pea teenei ki ngaa rohe e rua i meatia mai raa i mua e au. I teenei waa ko te kawa teetahi mea nui. Kai te ako ngaa taangata i nga aahua o te marae me kapa haka, kaaore he mea nui ngaa aahua o te ao whaanui. Mai i te wao o ngaa Poukai me ngaa Tekau-ma-rua eenei, mai i taaku Rohe Tuarua pea. I teenei waa ko ngaa waiata me te kapa haka ngaa mea nui i nga teihana pouwhakaata me ngaa teihana reo irirangi. Ko Te Matatini teetahi mea nunui ki nga kura.

There is also an issue of sense and of the direction of language. Perhaps this relates to language areas One and Two as suggested above. One emphasis in the way Maori is spoken 
now in Aotearoa is to do with ritual. Do people learn Maori to participate in te kawa o te marae and kapa haka rather than to talk about international affairs or even to talk about religion? It is as though one or two key areas of language development in the Poukai or Twelfths, set out as Area Two above, in the nineteenth century to do with kawa and waiata have become the meat and bread of the state language apparatus of education and media. Maori Television, especially the Te Reo station features replays of Kapa haka to a considerable extent. Te Matatini, the national kapa haka event and the regionals are sometimes the biggest things on school calendars now.

Kai runga i te whenua e kitea te haere tonu o te reo me te aahua o te tangata. $\mathrm{E}$ ai ki te kii, 'te reo moo oona aahuatanga'.

On the ground is a mix of language persistence and identity. This goes with the saying, 'the reo and its aspects'.

Kia huri ai te koorero ki te kapa haka ko te aahua o te kapa ko teenaa o te rohe, te iwi, te hapuu raanei. I ngaa ahurei ka kitea hokitia eetahi tirohanga whaanui rawa, aa, i eetahi waa ko te Maaoritanga te mea nui. Ka haria te aahua i ngaa waiata, i ngaa whaikoorero me te kawa o te kapa, te whakaaro ki ngaa taangata whenua hoki.

In the case of Kapa Haka this is the identity of the performance group which is usually also the identity of a whanau or hapu group and, at the festivals level, reflections of wider tribal groupings and of being Maori. This identity is expressed in karanga, haka, whaikorero and waiata, all formal language contexts.

I teenei waa he aahua uaua te tuu motuhake $\mathrm{i}$ te ao whaanui o te ipurangi kia whakaarongia te reo. Ko eenei aahua, rongo aahua ranei, e tika ana kia whakaarongia eenaa hai whakaaro-aa-motu e hookai ki te pooturi, ki te poouri raanei. He aahua kia mau ai moo teetahi waa poto noa.

Such identities or senses of such might well be considered in terms of what I have called simple or morbid nationalism above; the identity espoused momentarily for the competition or in the national case for the election perhaps lapses as soon as 
wider forces are brought into play. This is a very small society with many points of access to the outside world most or many of these now being through cyberspace where identity is moot in many respects especially with respect to language.

Ki te kapua, me kii, e kitea teetahi reo. Ko teenei reo ki te ipurangi e tautokongia naa e ngaa mihini i te AI kaaore he haangai ki teenaa whenua, teenaa? Kei te hoki te koorero pea ki a keegan me Cunliffe ( Ki a Higgins maa 2014) maa.

In the cloud, so to speak, as distinct from on the ground, the collection and digitisation of te reo with the advent of AI there is another language which is, on a sense, identity free or outside the mixes and messes of identity in a colonised political situation. This takes us back to consideration of theorists like keegan and Cunliffe (in Higgins et al. ed. 2014) and others as considered at the end of Monograph Three on Te Maataawai.

E tika ana pea kia whakaarongia anootia te diaspora (Temara me Mataamua ki Selby maa 2013) i te nuku o te reo ki te aatea.

It might also be worth reconsidering the idea of language diaspora (Temara and Maataamua in Selby et al. ed. 2013) as te reo spreads into cyberspace.

E tika ana pea kia whakaarongia te mahere o te reo. Ki tua o teenaa pea he tuhinga anoo o te mahere. Kia timata ai te koorero i taa Krupa mahere e tika ana kia whakaarongia te wao toorangapu mai i 1973. Kaaore a Krupa i whakaaro moo nga rerekeehanga o te ao toorangapu, ki Rarotonga, Ki Taahiti, Ki Aotearoa raanei. E tika ana kia whaia ai te mahere $\mathrm{i}$ te reo kaawatanaga o tena moutere teenaa.

This all seems to add up to a need for a consideration of the map. Then perhaps a redrawing of the map to see where the language is. Starting with Krupa's map of the the Polynesian language the political situation since 1973 may need to be considered. Krupa did not consider the political circumstances of the language in Rarotonga as compared to Tahiti under France or New Zealand under various local governments. And a map could and to some extent should be drawn to show the 
effect on the language of majority governments that favour English or colonial governments that favour French or local governments of speakers of the language as in Rarotonga.

E puta pea $i$ te mahere peenei he hua moo te whakatipuranga o te reo. Kia hoki ai te koorero ki ngaa mahere o te rohe tuatahi me te rohe tuarua ka whakaaro te tangata moo taa Marsden raaua ko Ruatara kauhau ki a Oihi. Kai te pehea te haere o te reo i teenei rohe inaaianei? Kai te aawangawanga haere?

Such a comparative map might yield important results for language development.

Coming back to the map of area one and area two the sermon at Oihi by Marsden and Ruatara comes to mind. That establishment of a reo that went to church and state might be seen in the context of a drawn out and to some extent a failedat least in an on time basis- set of Treaty Settlements. This, Area One, is also a centre for language uncertainty, delay and doubt and goes with the kind of morbidity and stalled dynamic described in terms of national identity earlier.

E tika ana kia whakaaro anootia te tapa i eenei waahi reo. He aha te ingoa moo te reo ki Ahitereiria, he aha te ingoa o te reo e koorerongia ki te ipurangi? He aha te ingoa mo te roopu reo e kiia naa ko 'Polynesian'? There is also a need now to consider the naming of new language spaces. What to call Maori spoken in Australia by people born there? What to call the language spoken and written on the internet? What to call the whole set of languages that were and still are called the Polynesian languages rightly or wrongly.

E tika ana hoki kia whakaarongia te rangahau o te Maaori tae hoki raa ki ngaa hiitore peenaa i taa Moon i runga i te paatai kua whai taatou i ngaa mahere tika, kaaore ranei?

With this may come a need to look at the anthropology of the Maori including language histories like Moon's in terms of the question; have we been following maps of a colonial and colonising kind? 
Kia hee ai te mahere naa te aha teenei? Ko teetahi mea pea ko te mahi whakauu i te iwi moo te reo hai taaonga. Kua whai teenei i ngaa aahuatanga o te Tiriti o Waitangi. Kai te tika te whakaaro ko te reo, he taonga?

\section{Te Tauira Tuarua: He mahere reo pea}

Model Two: Possible language maps

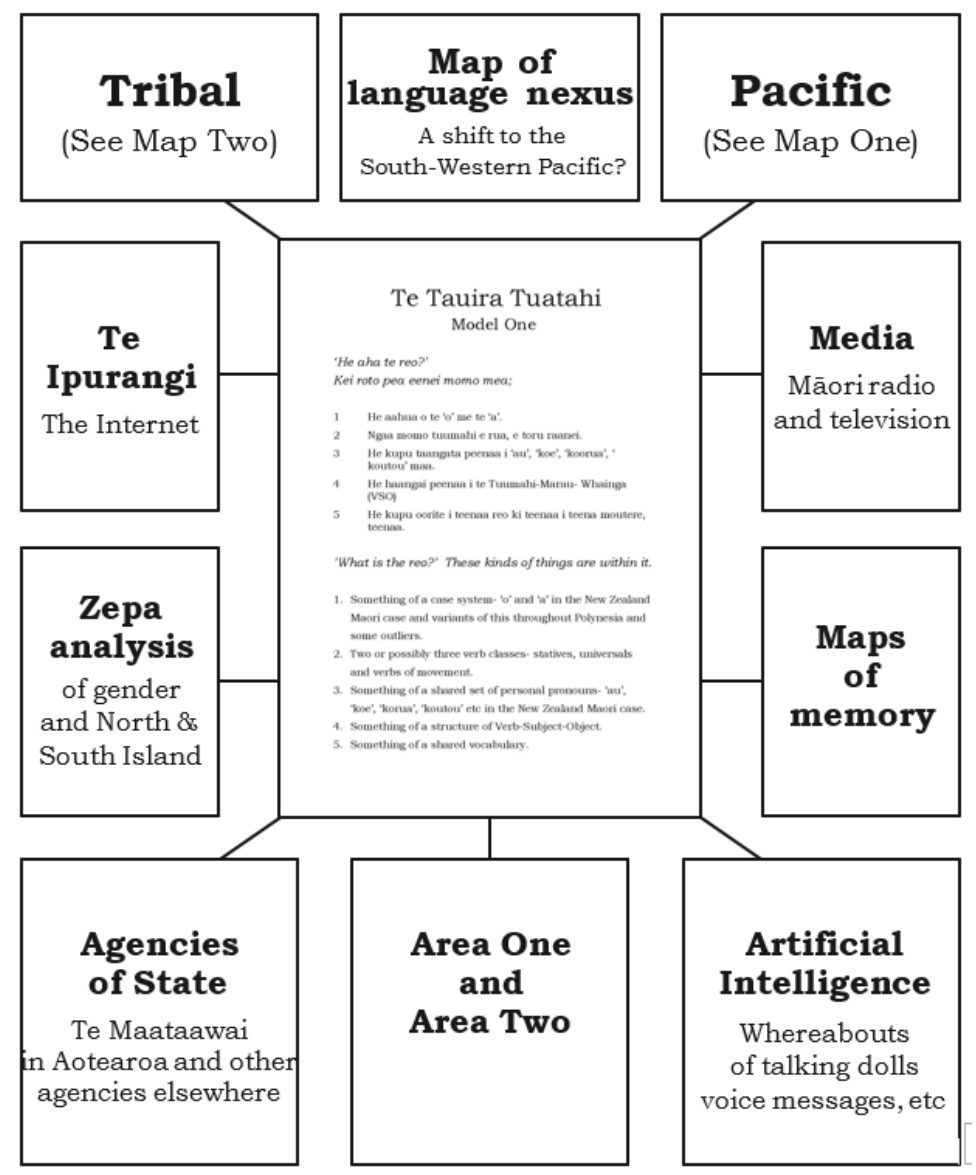


If the maps of language that we use are wrong in some way then why is this? There are two tendencies that we might look at here. One is the attention to tribe, to tribal rights that extend to rights over language as taonga, as precious possessions. (See Map Two)This of course follows Treaty of Waitangi claiming processes. Language as property may, at the end of the day be a cul de sac.

Ko te mea koorero, he peenaa teenaa i te mea tuatahi, e haangai teenei ki te rongo o te mahana naa ngaa koorero moo te aahua pooturi rawa atu o te motu i whakatakotongia naa e Sinclair maa. I teewhea toopito ka huri te whakaaro pooturi hai whakaaro poouri?

The second is similar to the first and to do with the false comfort of simple nationalism and this dates from the days of Keith Sinclair and others. At what point does simple misplaced nationalism become morbid?

I toona anoo naa waa, he mea nui te Kaawanatanga ki te reo inahoki ko teenaa te huarahi ki te maharatanga ki nga whare pukapuka me nga tari o te Kaawanatanga. He rerekee te mahi mahara o teenaa whenua teenaa pea. Engari inaaianei e rere eenei mea, ngaa mea mahara me te ao paho ki runga $i$ te ipurangi.

Nationalism or even the patronage of the nation state was important for endangered languages as it once offered the only route to memory and memorialization; the archives the documentation in official records, the museums the national radio and television also offered the only media route. These histories of nation-state are important in the idea of the endangerment of the language because of different memory captures.

But now these are offered, media and memory, by and on the internet.

He aha ngaa mea ki te mahere ki tua o Krupa? Ko te ipurangi, te hinegaro rorohiko, te matihikohanga o te reo me eetahi mea e tika ana kia maaheretia i eetahi wao pea. 
What are the things in the map beyond Krupa? There is the net and then there is $\mathrm{AI}$ and the digitisation of the language that needs to be included in something of a poly-dimensional map.

Ko eetahi mea e tika ana kia kitea ai ki te mahere, he mea uaua. Hai tauira ko Te Maataawai. Ki teenei waa kaaore anoo kia uu ai teenaa ahakoa hai toona anoo naa waa e kore e kore he mea nui teenaa.

Some things that might be or should be on the map are fuzzy and in flux. The best example might be Te Maataawai. At this stage it is still not settled and yet is potentially very important as the state organ, so to speak of te reo.

E hoki pea taatou ki te waa ngaawari o te mahere o Ani Salmond me nga taaone nui o Ruatoki, Tuurangawaewae, ngaa waahi warewaretia pea ki ngaa mahere Paakehaa. Inaaianei he uaua rawa te mahere. Kai te tika tonu taa Ani aro engari kua puta mai eetahi mea hou peenaa $i$ te mahi whakaako $i$ te reo $i$ ngaa kura, te reo irirangi Maori, te Pouwhakaaata Maaori me te ipurangi. He ahaa ngaa mahi mahere e tika ana kia taea ai inaaianei moo teenei?

We could go back to the good old days when things were simpler and

Anne Salmond talked about the Maori map with its tribal capitals like Ruatoki, Ngaruawahia and other places that were obscure in the Pakeha maps. Things are more complex now and perhaps they were even back in 1975 but there is still a map of marae, the Poukai, the Twelfths, the gatherings at Ratana pa to place on any map that points to the whereabouts of te reo.

Ko teetahi raruraru kaaore he taha ki te ipurangi, naa reira he uaua te mahi mahere. One problem with the internet and the map is that the internet has no centre and, perhaps, no edge. How to conceptualise the situation of te reo on the net? This applies to the media generally although Maori Television has been a central place for the last decade.

E tika ana kia pataingia kei hea nga puu o te reo? Kei a Krupa te orite o te mahere o te hinengaro me te reo korero tonu. I te tau 1975 ko te reo Maori o Rarotonga ka kitea tena ki reira, 
aa, ka kitea hokitia ki a Tamaki Maakau Rau engari ko Rarotonga tonu te puu, te toopito nui ki te mahere. I muri raa ka nuku tenei aahua o te reo ki a Aoteroa, ki a Ahitereiria, ki te hauaauru. He penei te nuku o te reo ki nga taaone ki a Aotearoa me te toro hoki ki a Ahitereiria. He wheenaa hoki teenaa ki te nuku o te reo o Sikaiana ki a Honiara, he nukuhanga ki te hauaauru hoki.

We might also ask what are the maps of repositories. Krupa has a direct equation of place physical and place mental in his map of the Polynesian languages. Cook Islands Maori was found around Rarotonga and at the time of Krupa's writing in 1973 spoken in parts of Auckland and elsewhere in New Zealand but Rarotonga would have been the main point on the map. Subsequently this form of the language moved west, like New Zealand Maori moved west to Australia and Soikaiana moved west to Honiara.

Kaaore anoo kia matihikohia te reo, kaaore anoo kia whakatuungia ki runga o te ipurangi. Naa reira kai ngaa kaikoorero tonu o te reo ngaa puu o te reo kaaore anoo kia whakatuungia ki waho i tetahi kohinga matihiko. The language is not yet digitised, not yet placed or situated on the web so the repository of language knowledge is still very much with speakers and not externalised in any kind of digital archive.

He aahua rerekee te reo Maori o Aotearoa ahakoa he tauira moo eetahi atu aahua o te reo. Ki te pukapuka o Salmond i 1975 teetahi mahere moo ngaa waahi nui moo ngaa hui, aa, ki ahau, he oorite eenei ki ngaa puu o te reo. Ahakoa kua whakatuungia te reo hai kaupapa ki ngaa whare waananga kaaore anoo ngaa whare wananga e tuu ana, ki tooku whakaaro hai puu moo te reo.

New Zealand Maori has a different mapping although it may be an example followed by other forms of the language. Salmond's 1975 map in her book Hui shows, I think, as well as a map of key hui places and 'Maori capitals', the locations of repositories of knowledge about te reo. Maori Studies at the University of Auckland is established and Maori departments 
are taking shape throughout New Zealand and the repository of the university has become a factor but is not, I think, in 1975, a major repository.

Ko te whakatuuranga o te Taura Whiri i te reo ki 1987, he nukuhanga ki te mahere o ngaa puu moo te reo. I teenei waa hoki, mai i 1975 ki teenei waa kua kitea te wao matihiko me te ipurangi, aa, ka whaingia te reo, oona puu me oona maharatanga ki te ipurangi.

Then there was the establishment of Te Taura Whiri i te Reo, itself a significant repository of knowledge and this is a shift in the map. Then there is the digital revolution and the internet which takes the language into accessible archives on the internet.

I teenaa waa hoki ko te aronga o teetahi whakatauki koa ki a Te Rangihau,

Hokia ki nga maunga kia purea ai koe e nga hau o Tawhirimatea, he whakaaro peenaa pea. Ka whai teenaa ai te aronga o te reo me oona ahuatanga.

At that time John Rangihau's exhortation;

Go back to the mountains to be purified by the winds of Tawhiti matea was in the same vein. In fact there is a fixing of the language to the culture as with te reo me oona aahua, the language and its aspects.

He rerekeehanga-aa-hapori i te rerekeehanga o te reo. Kia haere ai te tangata ki te hui, he mea whakawhanaunga teenaa. Ko te mahi ki runga ipurangi, te whakarongo ki te reo irirangi, te maatakitaki ki te pouwhakaata, he mea takitahi teenaa. Ka nuku te tangata pea $\mathrm{i}$ te ao o naaianei tonu ki teetahi wao hinengaro.

There are obvious social changes as the map of repositories and for te reo change. Going to hui is a social, kin based activity. Looking up something on the internet, hearing something on the radio or watching something on television are individual, socially isolated even as activities. There is also a sense that reality is being substituted or overtaken by an unreal world; the repository is in a virtual world. 
He mea oopurepure ngaa tae o teenei.. Kia whai ai te tangata i te kupu tika teeraa pea ka patai te tangata i te koroua, kuia ranei. Teeraa pea ka pao kee te tangata i te rorohiko kia whaia te kupu i te ipurangi.

It varies. To find an appropriate word people might ask an elder but also they might simply click on the Maori dictionary on the internet.

Kai te koorero taatou moo te mahere o ngaa reo motuhake, te mahere moo ngaa aahua o te reo ranei? Kei te moohio taatou ko taa Tuuhoe he aahua o te reo. Ka moohio hoki taaatou i te aro o teenei aahua reo i te nuku o te whenua naa te mahi ako, paho ranei o ngaa mea o Tuuhoe. Naa reira he mahere aahua reo, aa, he rerekeehanga rahi ki teenei.

Are we talking about a language map or a dialect map? We know that, say, the Tuuhoe speak a dialect. We know too that that dialect influences the way Maori is spoken by others as Tuuhoe teachers have gone across the country, newsreaders from Ruatoki have carried the news in Maori to people and so on. So there is a changing dialect map.

Ko eetahi waahi reo peenaa i te pouwhakaata Maaori, ka whakaitihia pea ngaa aahua reo ki reira. Engari i te reo irirangi Maaori me te Kapa Haka kaaore kau. He aha te mahere pai rawa? E whakaarongia anootia pea taa Capell (ki roo Krupa 1973) ki koonei moo ngaa aaahua reo. Ki a ia he aahua reo noa iho nga reo koorero o Polynesia, kaaore he mea motuhake.

Some transmission features like Maori Television seem to try and be dialect free or at least not to be impeded by dialect. Some maps such as the map of Kapa Haka and te reo are dialect centred as in some cases is the map of Maori radio and te reo. Are these retreats into dialect? Is this defensive as a strategy for language retention? All this is against the wider question as to whether all versions of the reo are dialects or stand alone entities and this goes back to Krupa's discussion of Capell who thought they were all dialects. 
I teetahi waa mooata $\mathrm{i}$ te hiitori o Niu Tireni he mea nui ngaa rohe. Mena kua peenaa te haere he nui rawa te whakaaro moo ngaa reo aa iwi?

At an early point in New Zealand's history provincialism was seriously considered. Had the country and its history been more province centred would that have made the language history more dialect based?

Kai hea te ripeka nui o te reo inaaianei, i hea teenei i ngaa waa o mua? I nga waa o neheraa ki Melanesia, te ripeka i mua $\mathrm{i}$ te nukuhanga ki a Polynesia. Inaaianei kua nuku ki te hauaauru pea ki a Aotearoa me Ahitereiria. Kua peenaa te nuku o te reo o Hamoa, o Tonga me eetahi atu reo peeraa.

Where is the nexus on the map now and where has the nexus been historically? At one far away point in time the nexus was in Melanesia before shifting East to Polynesia. Now there is western movement to New Zealand and Australia. Note that the shift to New Zealand and then to Australia has happened for Samoan, Tongan Cook Islands Maori and other language forms folowing migration the transmission of language in churches and in other ways.

Ko eetahi mahere ka haangai eenaa ki te ao toorangapu. Ko taaku mahi moo ngaa iwi i te rautau iwa tekau, e tika ana kia whakaarongia teenaa moo te rohe tuatahi me te rohe tuarua $i$ tuhia e au moo taa Moon. Ko taa Moon peenaa i te mahi naa Sinclair, naa Belich naa Sorenson maa, ka whai teenaa i te aahua o te Kaawanatanga ki Aotearoa.

Some maps are to do with politics. The present author's work on the early state in Mew Zealand Maori society maps in tandem with the mapping of area one and two taken from Moon earlier. Area one is kupapa while area two is rebel. Note that this is not Moon's own thesis but my interpretation of his work.

Moon's work itself is state centred like the work of Sinclair Belich and Sorenson before him. This is sovereignty centred and part of what the present author has described as a sovereignty game in earlier work. 
He patai ki koonei moo ngaa aahua o ngaa taangata, aa, e tika ana kia whakaaarongia te rahi o ngaa kaawanatanga ki te Moana nui a Kiwa me te whai naa teenaa teenaa $\mathrm{i}$ teetahi huarahi moo te reo.

There are issues of identity and one point is the number of colonial regimes in the pacific each with a different attitude to indigenous language retention.

I te tau 2017 kua puta mai teetahi ripoata moo te pouwhakaata Maaori (Zepa 2017). He mahere pea teenei i eetahi aahua. E haangai teenei ki eetahi roopu e toru; Zero, Passive me Active. Ko te roopu Zero, he Paakehaa te nuinga o eenei, he mea tata ki te ono tekau, mai i te Waipounamu hoki. Na reira e toru ngaa huringa. Ko eenei taangata kaaore raatou e huri ki te ao paho Maaori.

In 2017 Maori radio stations have been given a map of sorts through Zepa research which looks at Zero, Passive and Active speaking capacities. The Zero group are European, older and often live in the South Island so having three 'skews'. They, it is argued will only access Maori content through general media.

E rua ngaa wahanga o te roopu Passive. Ko te mea tuatahi, he Paakehaa te nuinga. I eetahi waa ka huri eenei taangata $\mathrm{ki}$ te ao reo Maaori tae hoki ki te ao paho Maaori. He whakaaro moo te ao matihiko ki teenei roopu.

The first passive group is predominantly European and is open to learning te reo but on an occasional basis with an interest in Maori topics. They have 'reasonable interest' in digital media.

Ko te wahanga tuarua o te roopu 'Passive', he rahi ngaa momo tangata ki teenei roopu, engari ko te nuinga he Paakehaa. Ko te pakeke kei waaenganui i ngaa tau 25 ki te 44 . Ka whai eenei taangata $i$ te ao matihiko me eetahi atu momo paho. Kai te reanga timata moo te reo eenei taangata, aa, kai te pirangi hoki eenei taangata ki te whakahaapai i too raatou reo.

The second Passive group is described as more multicultural but the report says that these Passive segments are predominantly European. 
Their age skew is 25-44 years. They access digital as well as other media. This group are at the beginner level in te reo with strong interest in improving.

Ko te roopu 'Active', he wahanga e rua hoki ki reira. Kai te huri eenei roopu e rua ki te taha waahine. Ko te nuinga o te roopu A2, he Maaori, aa, kai te huri te roopu A2 hai Maaori. E whai ngaa roopu e rua ki eetahi ao paho whaanui tae hoki raa ki te ao matihiko.

The Active group also divides in two. Both sets are described as strongly skewed to females. The A2 Active Speakers group is predominantly Maori while the A1 group has a Maori skew. Both groups access a range of media including digital.

He rerekee anoo te tuu o ngaa waahine moo te reo me te aahua, me kii, o te mahi whaikoorero ki runga marae. Teeraa pea ka koorero ngaa taane i te whaikoorero engari ka koorero ngaa waahine $\mathrm{i}$ te reo o te raa, te reo kai paraaoa pea. Ka puea ake ra ngaa patai.

It is different indeed, the position of women regarding the language and the way, for example, of men dominating speechmaking on the marae. This could mean that more men speak more formal language while more women speak everyday conversational Maaori. The questions bubble up in the mind...

Kia hoki ai te koorero ki taa Ani Salmond me taana maahere o 1975, he aahua rerekee teenei inaaianei. He mahere o te ao paho me te ipurangi, he mahere e huri ana ki te taha waahine te mahere reo Maori kia whai noatia te rangahau Zepa.

To go back to Anne Salmond's Maori map of 1975 in the book Hui there are some significant points of difference now. The map is media and net related now rather than rural, and rooted in the local mountain and river. The Maori map is also gendered at least as far as the Zepa analysis is concerned.

He ao anoo teenaa o 1975. Kia whakaarongia a Krupa me Salmond kai te mau eenaa $i$ te mahere o te ao tonu i runga i te whenua. I nga koroua, kuia, i o raatou anoo naa hinengaro te mahara o te reo. Ko raatou nga puukenga, ngaa pou herenga 
moo te reo. Engari inaaianei kei te iri te reo i te rangi. Kaaore he mea piri ki te whenua, te waa raanei.

It was a different world in 1975. If the work of Krupa 1973 and Salmond 1975 is considered this is a literal world that is being described, rooted in actual place. Where the language was spoken was where the repositories, the koroua and kuia in an oral culture were. By contast, the reo and its repositories is now in the air so to speak. It is not grounded in time and space.

I ngaa raa o Krupa me Salmond kia koorero ai te tangata I te reo e kore e kore ka noho eenaa taangata ki teetahi rohe aata moohiotia. He mea tata ki te marae ki te Haahi hoki. Inaaianei kee raa ko ngaa taangata e koorero ana i te reo he mea tata ana ki te reo irirangi, ki te pouwhakaata Maaaori, ki te ipurangi hoki. Teeraa pea kai te ao matauranga pea eenei kaikoorero, teeraa pea hoki e noho eenei ki teetahi diaspora ki waho o te hau kaainga, teeraa pea anoo e noho ana eenei ki waho o Polynesia.

In the days of Krupa and Salmond if a person spoke Maaori they would have been residents of a clearly defined locale, frequent visitors to marae and, perhaps, the church. Now a speaker might frequent media such as Maori Television radio or on the net or be involved in education somehow but they may live away from marae or church and even outside of Polynesia.

Kia hoki ai taatou ki te upoko o te pukapuka Hui,ko teetahi wao maatau nui moo te reo ko te kawa o te marae me te wharenui. Ko te haere o te kawa he mea nui kia whakaarongia hokitia ngaa pukapuka peenaa i Te Reo Rangatira e whai ana i te kawa hai aahua ako i te reo. Inaaianei ko te wao ako, kai waho pea i te marae, kai te ao paho pea.

If we go back to the title of the book Hui the kawa of the marae and the whare nui is a language leaning zone. In another book of that day, Te Reo Rangatira can be seen the emphasis on the Kawa as a language learing context. Now the learning zone might be away from the marae and perhaps in the media world.

Kia whakaarongia te waa, ko te mahara o te reo i ngaa waa ki mua, kua mau teenaa i te ao matihiko hai mea whakarongo 
inaaianei, ki ngaa waa e whai naa hoki. He mahara o ngaa mea katoa, o naaiatonumainei hoki.

Regarding time the memory of the language in the past is caught, ready to play in the present and here for the present, all via digital storage systems. There is instant recall and total recall of speech increasingly since, pretty well, the mid seventies the time of publication of Krupa and Salmond's books.

Teeraa pea he mea pai kia whakaaarongia te reo tata ki te mate moo eetahi momo taputapu.

It might be useful to consider the endangered language in terms of specific instrumentalities.

Ko ngaa mahere o te ao paho, he mea whakatoi ena. E ai ki a Zepa ko ngaa mea e whakarongo ana ki te reo irirangi he mea matatau kee ki te reo, a, ko ngaa mea e maatakitaki pouwhakaata, kaaore anoo.

The maps of the media are interesting. The Zepa analysis suggests that people listening to radio are already existing speakers of Maori while those who watch Maori Television may not be.

He peenaa te Maori ki Aotearoa ki te reo o Indonesia i te mea kua whakatuungia te reo ki koonei hai reo o te motu? Kia whakaarongia te orite o te reo Maaori o Rarotonga, o Ahitereiria kaaore teenei whakaaro $i$ te pai. He rahi rawa te whakatoorangapuuhanga o te reo ki koonei?

Is Maori like Indonesian? Has New Zealand Maori been invented or at least adapted to the New Zealand state? When, say Cook Islands Maori is compared this is clearly not the case as also with Maori speakers in Australia. And yet there is an assumption at large to do with identity and language here and this is seen in the scholarly literature in the work of Moon discussed above as well as in a general attitude foirst advanced by, perhaps Keith Sinclair and his generation of historians. Is this what people mean in the term, 'overpoliticization'?

Ki te mahi maahere e moemoetia peeneitia ai kai hea te reo? Kei waaenga pea i eetahi o ngaa maahere i wanangahia naa ki runga me eetahi atu hoki. Ko eenaa maahere pea moo ngaa 
taangata o te tuawhenua, moo te paakeke o te tangata, he wahine, taane raanei me te mahi ki te ipurangi. Kaaore noo te tuawhenua noa te reo, kaaore noo Polynesia noa hoki, aa, he rahi rawa ngaa waahine ki ngaa taane e koorero Maaori ana. He mea uaua ki te matakitaki te maahere engari e tika ana kia taea ai...

In the cartography so imagined, where is the reo? The answer might be that the reo is amongst the maps or even between the maps discussed so far and other maps to do with subjects as diverse as rural demography, age, gender, use of the internet. The reo is not necessarily a rural, community language. It is not necessarily a Polynesian language as in being based in Polynesia. If the Zepa analysis is correct it is now something of a gender skewed language with women being the primary speakers. The mapping is sketchy, the assumptions are many.... 


\section{Bibliography}

Bereiter, C and Scardamalia, M 1987 The Psychology of written composition, Erlbam

Capell,A 1933 The structure of oceanic languages Oceania 3: 418-34

1961-2 Interdisciplinary research on Polynesian origins, Oceania 32:28797

1962a Oceanic linguistics today Current Anthropology 3.4371 428

Cleave 1992 Kai signs, Seminar Paper to Te Hau Ora Tinana, Wellington

Cleave P 2015 E nga reo, tekaharoa.com

Fanon, F 1963 The Wretched of the Earth, Grove

Foote, K 1997 Shadowed ground: America's landscapes of violence and tragedy. University of Texas Press

Higgins, R, Rewi,P and Olsen Reeder V 2014 The Value of the Maori

Language Volume Two Huia Press

Kawharu, M 2010 Environment as a marae locale in Selby, Moore and Mulholland Ed.

Keegan, Te Taka and Cuncliffe, D 2014 Young People, Technology and the

Future of Te Reo Maori, in Higgins et alia eds pp385-398

Krupa, Viktor 1973. Polynesian languages: A survey of research The

Hague \& Paris. Mouton

Mahuta, Robert 1974 Whaikoorero: a study of formal Maori speech, Master of Arts thesis University of Auckland

Mitcalfe, B. (1974) Maori Poetry, the singing word. Victoria University

Press

Moon, Paul 2016 Ka ngaro te reo Otago University Press

Salmond, A Hui: A Study of Maori Ceremonial Gatherings A.H. and A.W.

Reed

Selby, R, Moore P and Mulholland M Maori and the Environment: Kaitiaki

Huia Press

Temara, P and Mataamua, R 2010 in Selby et alia eds

Sinclair, K 1959 A History of New Zealand. Pelican, 1959

Stephens, M and Monk P 2012 A language for buying biscuits? Maori as a civic language in the modern New Zealand Parliament, Australian Indigenous Law Review 
Waretini-Goddard R $2014 \quad 2014$ Transforming Maori experiences of historical intergenerational trauma Slide Show May 2014

Papers and reports

Zepa 2017 